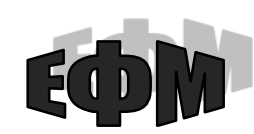

http://efm.vsau.org/

УАК 338.12

DOI: 10.37128/2411-4413-2019-9-2

\section{ФІНАНСОВО-ЕКОНОМІЧНИЙ СТАН ПІДПРИЕМСТВ АГРАРНОГО СЕКТОРУ ЕКОНОМІКИ ЧЕРКАСЬКОÏ ОБЛАСТІ ${ }^{\odot}$}

СОКОЛЮК С.ю., кандидат економічних наук, доцент, завідувач кафедри підприємництва, торгівлі та біржової діяльності Уманський національний університет садівництва

(м. Умань)

ФІЩУК Н.Ю.,

кандидат сільськогосподарських наук, доцент кафедри аграрного менеджменту,

Вінницький національний аграрний університет (м. Вінниця)

В статті проаналізовано середньорічну вартість та динаміку введення в дію нових основних засобів підприємств аграрного сектору економіки. Встановлено, щчо, починаючи з 2016 ., спостерігається тенденція до збільшення вартості основних засобів підприємств аграрного сектору, щзо призвело до збільшення темпів зростання виробництва аграрної продукиї та рентабельності. Виокремлено, що незважаючи на позитивні зрушення в динаміці введення нових основних засобів проблема оновлення основних засобів в підприємствах аграрного сектору області залишається невирішеною. Досліджено вартість оборотних засобів підприємств. Встановлена тенденція збільшення оборотних засобів у їх вартісному вираженні у підприємствах аграрного сектору області. Установлено значимість аналізу фінансово-економічного стану підприємств аграрного сектору за критеріями стійкості, платоспроможності та ділової активності, які розглядаються через призму показників структури капіталу, ліквідності та оборотності, щзо дає можливість кількісно оцінити вплив якості управління фінансовими ресурсами на рівень рентабельності та динаміку розвитку підприємств. За результатами аналізу діяльності підприсмств аграрного сектору області встановлено їх незадовільний фінансово-економічний стан. В зв'язку з иим запропоновано зміцнити матеріально-технічну базу підприємств, впровадити матеріало-, енерго- та трудозберігаючі технології; розробити і впровадити в аграрне виробництво прогресивні методи ведення господарства.

Ключові слова: аграрний сектор, підприємство, фінансові ресурси, показники ефективності, основні засоби, оборотні засоби, виробнича діяльність, розвиток.

Табл.: 2. Літ.: 8.

\title{
FINANCIAL AND ECONOMIC STATE OF ENTERPRISES OF THE AGRICULTURAL SECTOR OF ECONOMY IN CHERKASY REGION
}

\author{
SOKOLYUK Sergey, \\ candidate of economic sciences, associate professor, \\ Head of the Department of Entrepreneurship, Trade and Stock Exchange \\ Uman National University of Horticulture
} (Uman)

FISCHUK Natalia, associate professor of the Department of agrarian management, Vinnitsa National Agrarian University (Vinnytsia)

The article analyzes the average annual cost and dynamics of the introduction of new fixed assets of enterprises of the agricultural sector of economy. It is established that starting from 2016 there is a tendency to increase the value of fixed assets of enterprises of agricultural sector, which led to an increase 
in the growth rate of production of agrarian products and profitability. It is emphasized that in spite of positive changes in the dynamics of the new fixed assets introduction, the problem of fixed assets updating at the agricultural enterprises in the region remains unresolved. The tendency of operating assets value increase at the enterprises of the agricultural sector in the region is established. The significance of the analysis of the financial and economic state of agricultural enterprises according to the criteria of stability, solvency and business activity are considered through the prism of indices of capital structure, liquidity and turnover, which makes it possible to quantify the impact of quality management of financial resources on the level of profitability and dynamics of enterprise development. According to the results of the analysis of the enterprises of the agricultural sector of the region, their unsatisfactory financial and economic status was established. In this regard, it is proposed to strengthen the material and technical base of enterprises, to introduce material, energy and labor-saving technologies; develop and implement in agrarian production progressive methods of economy.

Key words: agrarian sector, enterprise, financial resources, indicators of efficiency, fixed assets, circulating assets, production activity, development.

Tabl.: 2. lit.: 8.

\title{
ФИНАНСОВО-ЭКОНОМИЧЕСКОЕ СОСТОЯНИЕ ПРЕДПРИЯТИЙ АГРАРНОГО СЕКТОРА ЭКОНОМИКИ ЧЕРКАССКОЙ ОБЛАСТИ
}

\author{
СОКОЛЮК С.ю., \\ кандидат экономических наук, доцент, \\ заведующий кафедрой предпринимательства, торговли \\ и биржевой деятельности \\ Уманский национальный университет садоводства \\ (2. Умань) \\ ФИЩУК Н.Ю.,

\section{кандидат сельскохозяйственных наук, доцент кафедры аграрного менеджмента} \\ Винницкий национальный аграрный университет \\ (2.Винница)
}

В статье проанализированы среднегодовую стоимость и динамику ввода в действие новых основных средств предприятий аграрного сектора экономики. Установлено, что начиная с 2016 2. Наблюдается тенденция к увеличению стоимости основных средств предприятий аграрного сектора, что привело к увеличению темпов роста производства аграрной продукции и рентабельности. Выделены, что несмотря на позитивные сдвиги в динамике ввода новых основных средств проблема обновления основных средств на предприятиях аграрного сектора области остается нерешенной. Исследована стоимость оборотных средств предприятий. Установлена тенденция увеличения оборотных средств в их стоимостном выражении на предприятиях аграрного сектора области. Выделены значимость анализа финансово-экономического состояния предприятий аграрного сектора по критериям устойчивости, платежеспособности и деловой активности, которые рассматриваются через призму показателей структуры капитала, ликвидности и оборачиваемости, что позволяет количественно оценить влияние качества управления финансовыми ресурсами на уровень рентабельности и динамику развития предприятий. По результатам анализа деятельности предприятий аграрного сектора области установлено их неудовлетворительное финансово-экономическое положение. В связи с этим, предлагаем укрепить материально-техническую базу предприятий, внедрить материало-, энергои трудосохраняющие технологии; разработать и внедрить в аграрное производство прогрессивные методы ведения хозяйства.

Ключевые слова: аграрный сектор, предприятие, финансовые ресурсы, показатели эффективности, основные средства, оборотные средства, производственная деятельность, развитие.

Табл.: 2. Лит.: 8.

Постановка проблеми. Інтеграція України до міжнародних спільнот, поглиблення економічних зв'язків, зростання конкуренції, необхідність модернізації виробництва та постійного запровадження інновацій зумовлюють використання вдосконалених методів і підходів щодо формування ринкових відносин в аграрному секторі. Формування ефективних, адаптованих до сучасних умов аграрних відносин і механізму управління ними неможливе без дослідження 
тенденцій та умов функціонування аграрного сектору, який виконує стратегічні завдання у національній економіці - гарантування продовольчої безпеки та формування конкурентних переваг країни у міжнародному економічному просторі. Саме тому оцінка та аналіз показників ефективності використання фінансових ресурсів підприємств аграрного сектору економіки $€$ актуальним аспектом дослідження.

Аналіз останніх досліджень і публікацій. Економічний зміст, особливості, проблеми аграрного сектору економіки займають провідне місце у працях вітчизняних вчених-економістів аграрного спрямування. Значний внесок у висвітлення питань формування та функціонування аграрного сектору економіки здійснили такі вітчизняні вчені, як В. Андрійчук, О. Боднар, П. Гайдуцький, Б. Губський, М. Дем'яненко, Т. Дудар, С. Кваша, М. Малік, П. Саблук, О. Шпичак та ін.

Питання сталого розвитку аграрної галузі у контексті реформування аграрного сектору економіки завжди є актуальним, вагомим у розвитку економіки країни. Саме проблеми розвитку аграрного сектору відображено у працях В. Бойка, В. Галушки, В. Горкавого, А. Даниленка, В. Зіновчука, В. Криворучка, М. Лобаса, Ю. Лупенка, В. Нелепа, О. Олійника, Л. Романової, П. Руснака, В. Савченка, М. Садикова, І. Сіваченка, В. Трегобчука, А. Третяка та ін.

Багато спірних питань щодо проблематики функціонування аграрного сектору були висвітлені у працях зарубіжних учених: Р. Нельсона, С. Уінтера, Деніса і Донелли Медоуз, Й. Рандерсона, Г. Дейлі, Л. Брауна, Г. Гарднера, Н. Картера, Ш. Лиле.

Незважаючи на вагоме висвітлення обраної теми досліджень існує необхідність постійного моніторингу стану та оцінки тенденцій розвитку задля виявлення та вирішення проблем підприємств аграрного сектору економіки .

Метою статті є висвітлення фінансово-економічного стану підприємств аграрного сектору економіки Черкаської області.

Виклад основних результатів дослідження. Формування ефективних, адаптованих до сучасних умов аграрних відносин і механізму управління ними неможливе без дослідження тенденцій та умов функціонування підприємств аграрного сектору, який виконує стратегічні завдання у національній економіці.

Для оцінки діяльності аграрних підприємств (на прикладі Черкаської області) розглянуто їхній виробничо-ресурсний потенціал та проаналізовано показники ефективності використання фінансових ресурсів. Рівень розвитку виробничо-ресурсного потенціалу підприємств аграрного сектору визначається, головним чином, ступенем насичення основними виробничими засобами, табл. 1.

Таблиия 1

Середньорічна вартість основних засобів підприємств аграрного сектору економіки Черкаської області, млн. грн*

\begin{tabular}{|c|c|c|c|c|c|c|}
\hline Показник & 2010p. & 2013p. & 2014p. & 2015p. & 2016p. & 2017p. \\
\hline $\begin{array}{c}\text { Середньорічна } \\
\text { вартість основних } \\
\text { засобів }\end{array}$ & 4032 & 3431 & 3360 & 3297 & 4321 & 4968 \\
\hline $\begin{array}{c}\text { Введенні в дію нові } \\
\text { основні засоби }\end{array}$ & 193 & 331 & 229 & 498 & 389 & 412 \\
\hline
\end{tabular}

*Джерело: [1, 2, 3]

За даними таблиці 1 до 2015 р. відбувалося зменшення наявності основних засобів підприємств аграрного сектору області та зниження їхньої вартості. У 2015 р. вартість основних засобів підприємств аграрного сектору знизилась на 735 млн грн порівняно 32010 p. Таке зменшення вартості основних засобів підприємств зазвичай є наслідком зменшення показника введення нових основних засобів або збільшення показника зношуваності основних засобів підприємств. Починаючи з 2016 р. спостерігається тенденція до збільшення вартості основних засобів підприємств аграрного сектору, що призвело до збільшення темпів зростання виробництва аграрної продукції та рівня рентабельності.

Вагоме значення для підтримання й зміцнення економічного потенціалу аграрних підприємств має розвиток їхньої матеріально-технічної бази шляхом введення в дію нових основних засобів та оновлення машинно-тракторного парку. Стабільної динаміки введення нових основних засобів в період 2010-2017 pр. на підприємствах аграрного сектору Черкаської області немає, що означає недостатнє зміцнення економічного потенціалу підприємств. Незважаючи на 
позитивні зрушення в динаміці, проблема оновлення основних засобів залишається невирішеною. Рівень фізичного зносу та морального старіння основних засобів підприємств аграрного сектору економіки Черкаської області високий - $41 \%$.

Виробнича діяльність підприємств аграрного сектору економіки повинна опиратися на детальну оцінку наявності у підприємствах аграрного сектору оборотних засобів, оскільки саме вони як засоби виробництва складають його основу [4]. До складу оборотних засобів відносяться виробничі запаси (насіння й садовий матеріал, фураж і підстилка, паливо - мастильні матеріали, запасні частини, мінеральні добрива), незавершене виробництво (витрати на роботи, виконані під урожай майбутнього року), молодняк тварин і тварини на відгодівлі [5].

Протягом 2010-2017 pр. відбулося збільшення оборотних засобів у їх вартісному вираженні у підприємствах аграрного сектору області. Так, у 2017 р. їхня вартість склала 15239874 млн грн, що на 11268031,8 тис. грн більше порівняно з 2010 p. За останні 5 років вартість оборотних засобів збільшилася на 3514795,7 тис. грн, це пов'язується із збільшенням цін у кормовиробництві. Дослідження діяльності підприємств аграрного сектору області показує, що нестача споруд для зберігання, переробних підприємств, транспортних засобів призводить до псування та втрат значної частини аграрної продукції, а диспропорції між робочими і силовими машинами не дозволяє ефективно використовувати всю аграрну техніку. Найбільш раціональна структура основних виробничих засобів у високоспеціалізованих підприємствах, де в одному технологічному процесі поєднано виробництво, зберігання і переробка аграрної продукції.

Особливе значення для оцінки та подальшого планування виробничої діяльності підприємств аграрного сектору має аналіз їхнього фінансово-економічного стану [6]: за критеріями стійкості, платоспроможності та ділової активності, які розглядаються через призму показників структури капіталу, ліквідності та оборотності, що дає можливість кількісно оцінити вплив якості управління фінансовими ресурсами на рівень рентабельності та динаміку розвитку підприємств, табл. 2.

Показники ефективності використання фінансових ресурсів підприсмств аграрного сектору Черкаської області

\begin{tabular}{|c|c|c|c|c|c|c|c|}
\hline Показник & $\begin{array}{c}\text { Нормативне } \\
\text { значення }\end{array}$ & 2013p. & $2014 p$. & 2015p. & 2016p. & 2017p. & $\begin{array}{c}\text { 2017p. до } \\
\text { 2013p., (+,-) }\end{array}$ \\
\hline 1 & 2 & 3 & 4 & 5 & 6 & 7 & 8 \\
\hline \multicolumn{8}{|c|}{ Показники рентабельності та динаміки розвитку } \\
\hline $\begin{array}{c}\text { Рентабельність } \\
\text { (збитковість) } \\
\text { власного капіталу, \% }\end{array}$ & $\begin{array}{c}>0, \\
\text { збільшення }\end{array}$ & 10,06 & 13,40 & 18,09 & 25,71 & 37,30 & $+27,24$ \\
\hline $\begin{array}{c}\text { Рентабельність } \\
\text { (збитковість) всього } \\
\text { капіталу, \% } \\
\end{array}$ & $\begin{array}{c}>0, \\
\text { збільшення }\end{array}$ & 5,05 & 5,40 & 14,50 & 15,30 & 16,00 & $+10,95$ \\
\hline $\begin{array}{c}\text { Рентабельність } \\
\text { (збитковість) } \\
\text { діяльності } \\
\text { підприємств, \% } \\
\end{array}$ & $\begin{array}{c}>0, \\
\text { збільшення }\end{array}$ & 10,19 & 12,00 & 12,41 & 25,10 & 41,00 & $+30,81$ \\
\hline $\begin{array}{c}\text { Індекс ділової } \\
\text { активності }\end{array}$ & $\begin{array}{c}>1, \\
\text { 3більшення } \\
\end{array}$ & 1,15 & 1,22 & 1,35 & 1,75 & 1,72 & $+0,57$ \\
\hline $\begin{array}{l}\text { Темпи зростання } \\
\text { чистого доходу }\end{array}$ & збільшення & 1,01 & 1,33 & 2,12 & 2,18 & 3,01 & +2 \\
\hline \multicolumn{8}{|c|}{ Показники ліквідності та ділової активності } \\
\hline Коефіціснт покриття & $>1$ & 1,90 & 1,80 & 1,70 & 1,62 & 1,59 & $-0,31$ \\
\hline $\begin{array}{c}\text { Коефіцієнт } \\
\text { оборотності активів }\end{array}$ & $>0,5$ & 0,43 & 0,55 & 0,59 & 0,66 & 0,69 & $+0,26$ \\
\hline $\begin{array}{c}\text { Коефіцієнт } \\
\text { оборотності } \\
\text { необоротних активів }\end{array}$ & $\begin{array}{c}<1, \\
\text { зменшення }\end{array}$ & 1,20 & 1,21 & 1,01 & 1,75 & 2,70 & $+1,50$ \\
\hline $\begin{array}{c}\text { Коефіцієнт } \\
\text { оборотності } \\
\text { оборотних активів }\end{array}$ & $\begin{array}{c}<0,1, \\
\text { зменшення }\end{array}$ & 0,71 & 0,69 & 0,80 & 0,88 & 0,90 & $+0,19$ \\
\hline \multicolumn{8}{|c|}{ Показники фінансової активності } \\
\hline $\begin{array}{c}\text { Коефіцієнт } \\
\text { фінансової автономії }\end{array}$ & $0,4-0,6$ & 0,54 & 0,50 & 0,49 & 0,42 & 0,48 & $-0,06$ \\
\hline
\end{tabular}




\section{http://efm.vsau.org/}

Продовження табл. 2

\begin{tabular}{|c|c|c|c|c|c|c|c|}
\hline 1 & 2 & 3 & 4 & 5 & 6 & 7 & 8 \\
\hline $\begin{array}{c}\text { Коефіцієнт } \\
\text { концентрації } \\
\text { позикового капіталу }\end{array}$ & збільшення & 0,45 & 0,47 & 0,50 & 0,59 & 0,62 & $+0,17$ \\
\hline $\begin{array}{c}\text { Коефіцієнт } \\
\text { співвідношення } \\
\text { власного і позикового } \\
\text { капіталів }\end{array}$ & $>0,5$ & 1,23 & 0,94 & 0,72 & 0,62 & 0,69 & $-0,54$ \\
\hline
\end{tabular}

*Джерело: [4, 5]

За результатами аналізу показників, наведених у табл. 2, економічний ефект від використання наявних ресурсів, виражений через систему економічних показників та коефіцієнтів, підтверджує взаємозалежність обсягу використаних ресурсів, дохідності та ефективності використання активів.

За досліджуваний період тенденцію до зменшення мали: коефіцієнт покриття на 0,31. Нормативне значення цього коефіцієнта в рамках 1-3, однак більш бажаним є значення 2-3.

Розрахований нами показник на основі фінансових даних підприємств аграрного сектору Черкаської області знаходиться в межах норми, але його зменшення засвідчує про проблемний стан платоспроможності, адже оборотних активів недостатньо для того, щоб відповісти за поточними зобов'язаннями.

Розраховане значення коефіцієнта фінансової автономії знаходиться в межах норми, а його зменшення за досліджуваний період засвідчує про високий рівень фінансових ризиків в діяльності підприємств аграрного сектору.

Розрахований коефіцієнт співвідношення власного і позикового капіталів знаходиться в межах норми, а зменшення його значення означає неповне використання фінансового та виробничого потенціалу підприємств [7].

Таким чином, проведений аналіз ефективності використання фінансових ресурсів аграрних підприємств Черкаської області свідчить про нестачу фінансових ресурсів, що негативно впливає на виробничо-господарську діяльність, спричиняє виникнення та зростання заборгованостей перед суб'єктами господарювання по оплаті праці, сплаті податків. При цьому зменшуються можливості фінансування подальшого їхнього розвитку, скорочуються надходження до бюджету.

Висновки. Отже, вітчизняний аграрний сектор має значний земельний та трудовий потенціал, але його подальший гармонійний розвиток потребує: зміцнення матеріально-технічної бази, заміни діючих ресурсо- та трудомістких технологій на матеріало-, енерго- та трудозберігаючі; розробці і впровадженні в аграрне виробництво прогресивних методів ведення господарства, в основі яких лежать методи ефективного виробництва продукції; використанні нової кадрової політики; розвиток напряму екологізації та органіки.

I саме аналіз та оцінка фінансово-економічного стану підприємств аграрного сектору Черкаської області $є$ основою для подальшого стратегічно-гармонійного розвитку аграрного сектору економіки в цілому.

\section{Список використаних джерел}

1. Офіційний сайт Управління агропромислового розвитку Черкаської ОДА. Веб-сайт. URL: http://www.dapr.ck.ua (дата звернення: 17.02.2019).

2. Статистичний щорічник Черкаської області за 2017 рік / За ред., В. П. Приймак. Черкаси: Головне управління статистики у Черкаській області, 2018. 419 с.

3. Офіційний сайт Міністерства аграрної політики та продовольства України. Веб-сайт. URL: http://www.minagro.gov.ua. (дата звернення: 19.02.2019).

4. Кобзєв I. С. Проблеми раціонального використання та відтворення природного ресурсного потенціалу в аграрній сфері України. АгроІнком. 2011. № 10-12. URL: http://www.nbuv.gov.ua /portal/chem_biol/agroin/2011_10-12/KOBZEV.pdf (дата звернення: 19.02.2019)

5. Лещик I. Б., Пиріг Г. І. Організаційно-економічні трансформації в аграрному секторі економіки. Сталий розвиток економіки. 2013. № 3. С. 327-331.

6. Дем'яненко М. Я. Фінансові проблеми формування та розвитку аграрного ринку. Облік $i$ фінанси АПК. 2010. № 5. С. 6.

7. Інноваційна Україна 2020: національна доповідь / За ред. В. М. Гейця та ін.; Київ: НАН України. 2015. 336 c. URL: http:// ief.org.ua/docs/nr/4pdf. (дата звернення: 07.03.2019) 


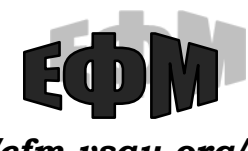

http://efm.vsau.org/

8. Стратегія розвитку Черкаської області на період до 2020 року. Веб-сайт. URL: http://www.ck-oda.gov.ua/docs/2015/strategy_2020.pdf (дата звернення: 09.03.2019)

\section{References}

1. Official site of the Agroindustrial Development Department of Cherkasy Regional State Administration [Site of the Agroindustrial Development] dapr.ck.ua Retrieved from: http://www.dapr.ck.ua [in Ukrainian].

2. Priymak, V. P. (Eds.). (2018). Statistical yearbook of Cherkasy region for 2017. [Statistics in Cherkasy Oblast 2017 r.] Cherkasy: The Main Department of Statistics in Cherkasy Oblast [in Ukrainian].

3. Official site Ministry of Agrarian Policy and Food of Ukraine. [Site of the Ministry of Agrarian Policy and Food of Ukraine] minagro.gov.ua. Retrieved from: http://www.minagro.gov.ua.

4. Hryshchenko, O.F. (2012). Doslidzhennia sutnosti problemy: mistse ta rol v protsesi rozroblennia ta pryiniattia marketynhovykh innovatsiinykh rishen [Investigation of the problem: place and role in the development and adoption of innovative marketing solutions]. Efektyvna ekonomika - Effective economy, 7. Retrieved from http://www.economy. nayka.com.ua/?op=1\&z=1289\&p=1 [in Ukrainian].

5. Kobzev, I.S. (2011) Problemu rationalnogo vukorustanni ta vidtvorenni prurodnogo resyrsnogo potenzialy v agrarniy sferi Ukrainu [Problems of rational use and reproduction of natural resource potential in the agrarian sector of Ukraine] AgroInkom 10-12. Retrieved from http://www.nbuv.gov.ua /portal/chem_biol/agroin/2011_10-12/KOBZEV.pdf [in Ukrainian].

6. Demyanenko, M.Ya., (2010) Finansovi problemu formyvanni ta rozvutky agrarnogo runky [Financial problems of the formation and development of the agrarian market]. Oblik i finansu APK Accounting and finance of agroindustrial complex, 5, 6. - 9. Retrieved from http://mmi.fem.sumdu.edu.ua/sites/default/files/ mmi2011_4_1_55_66.pdf [in Ukrainian].

7. Geits V.M. (Eds.). (2015). Innovaziyna Ukraina 2020 nazionalna dopovid [Innovative Ukraine 2020: National Report]. Kyiv: NAN Ukraine. 336. URL: http:// ief.org.ua/docs/nr/4pdf. (дата звернення: 10.03.2019) [in Ukrainian].

8. Cherkasy region development strategy for the period till 2020 [Site of the Cherkasy region development strategy] ck-oda.gov.ua. Retrieved from: http://www.ck-oda.gov.ua /docs/2015 /strategy_2020.pdf [in Ukrainian].

\section{Інформація про автора}

СОКОЛЮК Сергій Юрійович - кандидат економічних наук, доцент, завідувач кафедри підприємництва, торгівлі та біржової діяльності. Уманський національний університет садівництва (20300, вул. Інтернаціональна 4/10, кв. 8, м. Умань, sergey.unys@gmail.com).

ФІЩУК Наталія Юріївна - кандидат сільськогосподарських наук, доцент кафедри аграрного менеджменту, Вінницький національний аграрний університет (21008, м.Вінниця, вул.Сонячна, 3, e-mail: natalfis2016@gmail.com)

SOKOLYUK Sergyi - Associate Professor, Head of Department of Business, Trade and Exchanges Activities. Uman,. Uman National University of Horticulture, Ukraine. (20300, вул. Інтернаціональна 4/10, кв. 8, м. Умань, sergey.unys@gmail.com)

FISCHUK Natalia - associate professor of the Department of agrarian management,Vinnytsia National Agrarian University (21008,Vinnytsia, 3, Sonyachna str., e-mail:natalfis2016@gmail.com)

СОКОЛЮК Сергей Юрьевич - кандидат экономических наук, доцент, заведующий кафедрой предпринимательства, торговли и биржевой деятельности. Уманский национальный университет садоводства (20300, ул. Интернациональная 4/10, кв. 8, г. Умань, sergey.unys@gmail.com)

ФИЩУК Наталия Юрьевна - кандидат сельскохозяйственных наук, доцент кафедры аграрного менеджмента, Винницкий национальный аграрный университет $(21008$, г. Винница, ул. Солнечная, 3, e-mail: natalfis2016@gmail.com) 